\title{
Blood biochemical profiles of Brahman crossbred cattle supplemented with different protein and energy sources
}

\author{
Nguyen Hong Xuan ${ }^{1}$, Huynh Tan Loc ${ }^{2}$ and Nguyen Trong $\mathrm{Ngu}^{2}$
}

1. Department of Food Technology, College of Food Technology and Biotechnology, Can Tho University of Technology, Can Tho, Vietnam; 2. Department of Veterinary Medicine, College of Agriculture and Applied Biology, Can Tho University, Can Tho, Vietnam.

Corresponding author: Nguyen Trong Ngu, e-mail: ntngu@ctu.edu.vn Co-authors: NHX: nhxuan@ctuet.edu.vn, HTL: tanloc@ctu.edu.vn

Received: 28-03-2018, Accepted: 05-06-2018, Published online: 31-07-2018

doi: 10.14202/vetworld.2018.1021-1024 How to cite this article: Xuan NH, Loc HT, Ngu NT (2018) Blood biochemical profiles of Brahman crossbred cattle supplemented with different protein and energy sources, Veterinary World, 11(7): 1021-1024.

\begin{abstract}
Aim: The experiment was carried out to evaluate the effects of supplementing different levels of protein and energy sources on blood biochemical profiles of Brahman crossbred cattle.

Materials and Methods: The study consisted of two experiments in Brahman crossbred cattle in An Giang Province. In trial 1,28 cattle of $178 \pm 12.5 \mathrm{~kg}$ were arranged in a completely randomized block design. In the second trial, another 24 cattle of $182 \pm 14.3 \mathrm{~kg}$ were allocated in a $2 \times 3$ factorial design. The experiments lasted for 90 days. Blood samples were taken at the end of the experiments, and plasma concentrations of metabolites and enzymes were analyzed by an automated biochemical analyzer (Humalyzer 3000, USA).

Results: The glucose concentration was highest at $1.83 \mathrm{mmol} / \mathrm{L}$ when supplemented with urea $(60 \mathrm{~g} / \mathrm{head} / \mathrm{d})$. Urea and creatinine content was not significantly different between treatments when cattle were supplemented with different protein and energy sources. In the treatment with $360 \mathrm{~g} / \mathrm{head} / \mathrm{d}$ soybean meal supplementation, cholesterol concentration was lowest $(2.50 \mathrm{mmol} / \mathrm{L})$, compared with the highest concentration $(3.86 \mathrm{mmol} / \mathrm{L})$ in the treatment with soybean meal at $720 \mathrm{~g} / \mathrm{head} /$ day. The total protein concentration showed the highest values at $94.5 \mathrm{~g} / \mathrm{L}$ and $96.3 \mathrm{~g} / \mathrm{L}$ when supplemented with soybean meal (720 g/head/day) and fish oil, respectively.
\end{abstract}

Conclusion: There were slightly altered blood biochemical profiles among cattle at different protein and energy source supplements.

Keywords: cattle, concentrate, oil, soybean, supplementation.

\section{Introduction}

Feeding and rearing systems play a pivotal role on the values of hematological and serum biochemical variables in raising animals [1-3]. Feed is an essential aspect of livestock production, and the importance of feed supplementation in animal production has substantially increased in recent years [4]. Nutritional status of an individual was dependent on dietary intake and effectiveness of metabolic processes, which can be determined using solely or a combination of chemical, anthropometric, biochemical, or dietary methods. In fact, a previous study has indicated that fish meal and soybean meal could be used as a source of protein in animal diets [5]. In addition, Hassan et al. [6] and Mamun et al. [3] stated that changes in biochemical and hematological constituents are major indicators of the physiological and pathological states of the animal.

Copyright: Xuan, et al. Open Access. This article is distributed under the terms of the Creative Commons Attribution 4.0 International License (http://creativecommons.org/licenses/by/4.0/), which permits unrestricted use, distribution, and reproduction in any medium, provided you give appropriate credit to the original author(s) and the source, provide a link to the Creative Commons license, and indicate if changes were made. The Creative Commons Public Domain Dedication waiver (http://creativecommons.org/ publicdomain/zero/1.0/) applies to the data made available in this article, unless otherwise stated.
Therefore, the biochemical determination of serum constituents and blood examination can provide valuable information relating to nutrition and other environmental factors that influence the performance and well-being of animals [7-9]. Serum concentrations of metabolites such as glucose, cholesterol, non-esterified fatty acids, blood urea nitrogen, creatinine, total proteins, albumin, globulin, and minerals are commonly used to assess the nutritional status of cattle.

The present study was conducted to explore the effects of different protein and energy sources on blood chemical profiles of Brahman crossbred cattle.

\section{Materials and Methods}

\section{Ethical approval}

This study was carried out after obtaining approval (No. 01/NCCB) from Can Tho University and An Giang Department of Veterinary Medicine.

\section{Animals and design}

The study consisted of two experiments in Brahman crossbred cattle in An Giang Province, Vietnam $\left(10^{\circ} 23^{\prime} \mathrm{N}, 105^{\circ} 26^{\prime} \mathrm{E}\right)$. In trial 1, 28 animals of $178 \pm 12.5 \mathrm{~kg}$ were arranged in a completely randomized block design. The basal diet consisted 
of Hymenachne acutiglum grass, rice straw, and rice bran $(1.5 \mathrm{~kg} / \mathrm{head} / \mathrm{d})$, and other treatments were with different protein sources and levels such as urea (U1, $60 \mathrm{~g} / \mathrm{head} / \mathrm{d}$, and $\mathrm{U} 2,120 \mathrm{~g} / \mathrm{head} / \mathrm{d}$ ), soybean meal (SM1, $360 \mathrm{~g} / \mathrm{head} / \mathrm{d}$, and SM2, $720 \mathrm{~g} / \mathrm{head} / \mathrm{d}$ ), and $50 \%$ blood meal and $50 \%$ feather meal mixture (BFM1, $360 \mathrm{~g} / \mathrm{head} / \mathrm{d}$, and BFM2, $720 \mathrm{~g} / \mathrm{head} / \mathrm{d}$ ). In the second trial, 24 cattle of $182 \pm 14.3 \mathrm{~kg}$ were allocated into a $2 \times 3$ factorial design with two levels of concentrate supplement $(0.5 \%$ and $1.5 \%$ body weight $)$ and three supplemental sources (no oil, $60 \mathrm{~g}$ soybean oil $/ \mathrm{kg}$ dry matter [DM], and $60 \mathrm{~g}$ fish oil $/ \mathrm{kg} \mathrm{DM})$. The resulting six treatments were $0.5 \%$ concentrate supplement without oil, $1.5 \%$ concentrate supplement without oil, $0.5 \%$ concentrate plus soybean oil supplement, $1.5 \%$ concentrate plus soybean oil supplement, $0.5 \%$ concentrate plus fish oil supplement, and $1.5 \%$ concentrate plus fish oil supplement. The experiments lasted for 90 days.

\section{Blood collection and analysis}

At the end of the feeding trials, about $10 \mathrm{ml}$ of blood samples were collected into tubes containing $10 \%$ sodium heparin. Samples were then centrifuged at $1000 \mathrm{rpm}$ for $20 \mathrm{~min}$ at $4^{\circ} \mathrm{C}$, and plasma was separated for laboratory analysis. The plasma concentrations of metabolites (glucose, urea, creatinine, uric acid, bilirubin, and cholesterol), protein (total protein, albumin, and globulin), and enzymes (aspartate aminotransferase and alanine aminotransferase [ALT]) were analyzed by an automatic biochemical analyzer (Humalyzer 3000, USA).

\section{Statistical analysis}

Data were subjected to the analysis of variance in Minitab 16 Statistical Software using appropriate models as in the experimental design, and Tukey's multiple test was used to determine the differences between means at the significant level of $p<0.05$ [10].

\section{Results}

Table-1 shows that the differences between protein source supplementations also altered the cattle's blood biochemical profiles. Glucose concentration was reduced in all treatments compared with basal treatment, except an increased glucose concentration in U1 treatment; glucose concentration in U1 treatment was higher than SB1, and the difference was statistically significant $(p<0.05)$. Total protein concentration of all treatments was higher than that of the basal treatment. In SB2 treatment, the concentration was higher than that in basal treatment, and it was significantly different $(\mathrm{p}<0.05)$. There was a change in the composition of total bilirubin and direct bilirubin in $\mathrm{U} 1$ treatment at $29.67 \mu \mathrm{mol} / \mathrm{L}$ and $15.7 \mu \mathrm{mol} / \mathrm{L}$ and $5.23 \mu \mathrm{mol} / \mathrm{L}$ and $2.07 \mu \mathrm{mol} / \mathrm{L}$ higher than in SB1 treatment, respectively. This distinction was statistically significant $(p<0.05)$. Cholesterol concentration also varied between treatments. In SB2 treatment, the cholesterol concentration was $3.86 \mathrm{mmol} / \mathrm{L}$ higher than that of the basal treatment with $3.43 \mathrm{mmol} / \mathrm{L}$, and the difference was statistically significant $(p<0.05)$. Urea concentration slightly increased in the treatments compared with the basal treatment, except a decrease in U1 treatment. However, the difference was not statistically significant.

Supplementing different concentrate levels and energy sources also changed the blood biochemical profiles of cattle (Table-2). In treatments without soybean oil and fish oil supplementation, the uric acid concentration was highest at $193.5 \mu \mathrm{mol} / \mathrm{L}$ and

Table-1: Enzyme activities and concentrations of proteins and metabolites in blood of cattle supplemented with different protein sources and levels $(n=28)$.

\begin{tabular}{|c|c|c|c|c|c|c|c|c|c|c|}
\hline \multirow[t]{2}{*}{ Parameters } & \multirow[t]{2}{*}{$\mathbf{n}$} & \multicolumn{7}{|c|}{ Diets } & \multirow[t]{2}{*}{ SEM } & \multirow[t]{2}{*}{ p-value } \\
\hline & & Basic & U1 & $\mathbf{U 2}$ & SB1 & SB2 & BFM1 & BFM2 & & \\
\hline \multicolumn{11}{|l|}{ Metabolites } \\
\hline Glucose (mmol/L) & 28 & $1.67^{\mathrm{ab}}$ & $1.83^{a}$ & $1.73^{\mathrm{ab}}$ & $0.57^{b}$ & $1.55^{\mathrm{ab}}$ & $1.31^{\mathrm{ab}}$ & $0.73^{a b}$ & 0.258 & 0.014 \\
\hline Urea $(\mathrm{mmol} / \mathrm{L})$ & 28 & 4.47 & 4.33 & 4.47 & 5.83 & 5.35 & 7.00 & 6.40 & 0.621 & 0.061 \\
\hline Creatinine ( $\mu \mathrm{mol} / \mathrm{L})$ & 28 & 63.67 & 63.67 & 68.00 & 69.00 & 78.25 & 73.99 & 61.67 & 5.403 & 0.355 \\
\hline Uric acid ( $\mu \mathrm{mol} / \mathrm{L})$ & 28 & 61.67 & 156.33 & 49.67 & 55.67 & 64.75 & 171.33 & 73.00 & 34.012 & 0.128 \\
\hline Total bilirubin ( $\mu \mathrm{mol} / \mathrm{L})$ & 28 & $8.33^{a b}$ & $29.67^{a}$ & $11.3^{\mathrm{ab}}$ & $5.23^{b}$ & $16.55^{\mathrm{ab}}$ & $15.19^{\mathrm{ab}}$ & $9.48^{\mathrm{ab}}$ & 4.774 & 0.042 \\
\hline Direct bilirubin $(\mu \mathrm{mol} / \mathrm{L})$ & 28 & $4.83^{\mathrm{ab}}$ & $15.7^{a}$ & $7.50^{\mathrm{ab}}$ & $2.07^{b}$ & $5.39^{\mathrm{ab}}$ & $6.62^{\mathrm{ab}}$ & $2.70^{\mathrm{b}}$ & 2.664 & 0.039 \\
\hline Indirect bilirubin $(\mu \mathrm{mol} / \mathrm{L})$ & 28 & 3.50 & 13.63 & 3.80 & 3.18 & 11.21 & 8.53 & 6.77 & 2.634 & 0.072 \\
\hline Cholesterol (mmol/L) & 28 & $3.43^{b}$ & $3.73^{\mathrm{ab}}$ & $3.83^{\mathrm{ab}}$ & $2.50^{\mathrm{b}}$ & $3.86^{a}$ & $3.46^{\mathrm{ab}}$ & $4.97^{\mathrm{ab}}$ & 0.308 & 0.002 \\
\hline \multicolumn{11}{|l|}{ Protein } \\
\hline Total protein (g/L) & 28 & $81.0^{\mathrm{b}}$ & $90.0^{\mathrm{ab}}$ & $90.0^{\mathrm{ab}}$ & $89.3^{\mathrm{ab}}$ & $94.5^{\mathrm{a}}$ & $90.6^{\mathrm{ab}}$ & $89.0^{\mathrm{ab}}$ & 2.133 & 0.017 \\
\hline Albumin $(\mathrm{g} / \mathrm{L})$ & 28 & 40.0 & 41.0 & 39.3 & 39.7 & 41.8 & 39.9 & 40.7 & 1.639 & 0.946 \\
\hline Globulin ( $\mathrm{g} / \mathrm{L})$ & 28 & $41.0^{\mathrm{b}}$ & $49.0^{\mathrm{ab}}$ & $50.7^{\mathrm{ab}}$ & $53.0^{\mathrm{a}}$ & $53.3^{a}$ & $50.5^{\mathrm{ab}}$ & $48.3^{\mathrm{ab}}$ & 2.452 & 0.042 \\
\hline \multicolumn{11}{|l|}{ Enzymes } \\
\hline AST (U/L) & 28 & 37.7 & 27.3 & 31.3 & 30.7 & 24.8 & 19.3 & 26.7 & 4.322 & 0.215 \\
\hline ALT (U/L) & 28 & 18.0 & 14.7 & 20.7 & 20.7 & 26.5 & 13.8 & 17.3 & 2.798 & 0.091 \\
\hline
\end{tabular}

Basic diet: Hymenachne acutiglum grass, rice straw, and rice bran (1.5 kg/head/d); U1, U2, SB1, SB2, BFM1, and BFM2: Supplements of urea (U1, $60 \mathrm{~g} / \mathrm{head} / \mathrm{d}$, and U2, $120 \mathrm{~g} / \mathrm{head} / \mathrm{d})$, soybean meal (SM1, $360 \mathrm{~g} / \mathrm{head} / \mathrm{d}$, and SM2, $720 \mathrm{~g} / \mathrm{head} / \mathrm{d}$ ), and $50 \%$ blood meal and 50\% feather meal mixture (BFM1, $360 \mathrm{~g} / \mathrm{head} / \mathrm{d}$, and BFM2, $720 \mathrm{~g} / \mathrm{head} / \mathrm{d}$ ). $\mathrm{SEM}=$ Standard error of the means, $\mathrm{AST}=$ Aspartate aminotransferase, $\mathrm{ALT}=$ Alanine aminotransferase. ${ }^{\mathrm{a}, \mathrm{b}}$ Means bearing different superscripts within a row differ significantly $(p<0.05)$ 
Table-2: Enzyme activities and concentrations of proteins and metabolites in blood of cattle supplemented with different concentrate levels and energy sources $(n=24)$.

\begin{tabular}{|c|c|c|c|c|c|c|c|c|c|c|c|}
\hline \multirow[t]{2}{*}{ Parameters } & \multirow[t]{2}{*}{$\mathbf{n}$} & \multicolumn{2}{|c|}{ Concentrate (C) } & \multirow[t]{2}{*}{ SEM } & \multicolumn{3}{|c|}{ Energy source (E) } & \multirow[t]{2}{*}{ SEM } & \multicolumn{3}{|c|}{ p-value } \\
\hline & & $0.5(\%)$ & $1.5(\%)$ & & - & so & FO & & C & $\mathbf{E}$ & CXE \\
\hline \multicolumn{12}{|l|}{ Metabolites } \\
\hline Glucose (mmol/L) & 24 & 1.3 & 1.5 & 0.1 & 1.7 & 1.3 & 1.3 & 0.2 & 0.132 & 0.112 & 0.635 \\
\hline Urea $(\mathrm{mmol} / \mathrm{L})$ & 24 & 5.8 & 5.7 & 0.2 & 5.3 & 5.9 & 6.1 & 0.3 & 0.789 & 0.120 & 0.179 \\
\hline Creatinine $(\mu \mathrm{mol} / \mathrm{L})$ & 24 & 69.3 & 67.3 & 3.8 & 64.2 & 72.0 & 68.8 & 4.7 & 0.728 & 0.521 & 0.045 \\
\hline Uric acid $(\mu \mathrm{mol} / \mathrm{L})$ & 24 & $97.7^{\mathrm{b}}$ & $145.2^{\mathrm{a}}$ & 11.3 & $193.5^{\mathrm{A}}$ & $67.7^{\mathrm{B}}$ & $103.0^{\mathrm{B}}$ & 13.9 & 0.012 & 0.000 & 0.000 \\
\hline Total bilirubin $(\mu \mathrm{mol} / \mathrm{L})$ & 24 & 10.3 & 16.7 & 3.9 & 23.5 & 7.8 & 9.3 & 4.7 & 0.257 & 0.069 & 0.031 \\
\hline Direct bilirubin $(\mu \mathrm{mol} / \mathrm{L})$ & 24 & 9.5 & 9.2 & 1.5 & $13.0^{\mathrm{A}}$ & $4.1^{\mathrm{B}}$ & $4.9^{\mathrm{B}}$ & 1.8 & 0.102 & 0.008 & 0.017 \\
\hline Indirect bilirubin $(\mu \mathrm{mol} / \mathrm{L})$ & 24 & 4.8 & 7.6 & 2.5 & 10.5 & 3.7 & 4.4 & 3.0 & 0.440 & 0.257 & 0.053 \\
\hline Cholesterol $(\mathrm{mmol} / \mathrm{L})$ & 24 & 3.7 & 3.3 & 0.1 & 3.5 & 3.6 & 3.3 & 0.2 & 0.070 & 0.484 & 0.784 \\
\hline \multicolumn{12}{|l|}{ Protein } \\
\hline Total protein $(\mathrm{g} / \mathrm{L})$ & 24 & 87.0 & 91.8 & 2.1 & $86.8^{A B}$ & $85.3^{\mathrm{B}}$ & $96.3^{A}$ & 2.6 & 0.128 & 0.021 & 0.682 \\
\hline Albumin $(\mathrm{g} / \mathrm{L})$ & 24 & $38.5^{\mathrm{B}}$ & $41.3^{\mathrm{A}}$ & 0.7 & $42.5^{A}$ & $39.0^{\mathrm{B}}$ & $38.3^{\mathrm{B}}$ & 0.8 & 0.013 & 0.009 & 0.278 \\
\hline Globulin ( $\mathrm{g} / \mathrm{L})$ & 24 & 48.5 & 50.5 & 2.1 & $44.3^{\mathrm{B}}$ & $46.3^{B}$ & $58.0^{\mathrm{A}}$ & 2.6 & 0.522 & 0.006 & 0.939 \\
\hline \multicolumn{12}{|l|}{ Enzymes } \\
\hline AST (U/L) & 24 & 30.0 & 28.7 & 2.1 & 30.5 & 25.8 & 31.8 & 2.6 & 0.667 & 0.271 & 0.016 \\
\hline ALT (U/L) & 24 & 16.2 & 18.3 & 1.2 & $19.0^{\mathrm{AB}}$ & $19.3^{\mathrm{A}}$ & $13.5^{\mathrm{B}}$ & 1.5 & 0.238 & 0.032 & 0.011 \\
\hline
\end{tabular}

SO=Soybean oil, FO=Fish oil, C=Concentrate, E=Energy source, -=No supplementation of either soybean oil or fish oil, Means bearing different superscripts within a row differ significantly $(p<0.05)\left({ }^{a, b}\right.$ Concentrate level, ${ }^{A, B}$ energy sources $)$. $\mathrm{SEM}=$ Standard error of the means, $\mathrm{AST}=$ Aspartate aminotransferase, $\mathrm{ALT}=$ Alanine aminotransferase

significantly different $(\mathrm{p}<0.05)$ compared with fish oil treatment, soybean oil treatment, and treatment at $0.5 \%$ concentrate supplement level. The concentration of total bilirubin and indirect bilirubin was also highest in treatments without soybean oil and fish oil, but there was no difference compared with the other treatments. Cholesterol concentration slightly increased from 3.3 to $3.7 \mathrm{mmol} / \mathrm{L}$ among treatments, and there was no statistically significant difference. The total protein concentration of fish oil treatment was $96.3 \mathrm{~g} / \mathrm{L}$, higher than that in treatment with soybean oil supplementation at $85.3 \mathrm{~g} / \mathrm{L}$, and the difference was statistically significant $(p<0.05)$. However, the concentration of ALT in fish oil supplementation at $13.5 \mathrm{U} / \mathrm{L}$ was 19.3 $\mathrm{U} / \mathrm{L}$, less than that in soybean oil treatment $(\mathrm{p}<0.05)$.

\section{Discussion}

The concentration of blood glucose content in the blood biochemical profiles was $0.57 \mathrm{nmol} / \mathrm{L}$ and $1.83 \mathrm{nmol} / \mathrm{L}$ for SB1 and U1 feeding treatments, respectively, and was comparable between that treatments which indicated a significant increase in feeding of U1 treatment though the values were within the upper normal limit reported by Kaczmarowski et al. [11] with blood glucose concentration of healthy cows $(2.54 \pm 0.88 \mathrm{mmol} / \mathrm{L})$. The blood glucose concentration is one of the biochemical indicators by which one may conclude about body energy supply. In addition, there was no significant difference in serum total protein supplemented by different concentrate levels and energy sources. In male buffalo calves consuming wheat straw and concentrate mixture, Kumar and Dass [12] also reported non-significant effect of niacin supplementation on serum glucose level, serum total protein, albumin, and globulin in blood biochemical profiles. Albumin reflects long-term protein status, and plasma albumin levels could be altered by the effect of liver function, protein, and energy intake, age, and protein losses during certain diseases such as parasitism. Moreover, the concentration of total protein, globulin, albumin, and urea-N in blood serum is indicators of the adequacy or inadequacy of nitrogen in the diet of animals [13]. In this study, albumin levels and globulin were similar to those reported by Alves et al. [14] in dairy cows.

Inside the body of animals, cholesterol is synthesized from fatty acids and its concentration in the serum reflects body fat metabolism. In the present study, the availability of cholesterol in blood serum was found significantly different between SB2 and basal treatment $(p<0.01)$. This was probably due to the higher intake of fibrous diets in basal treatment which is responsible for lowering the cholesterol content in serum [15]. In addition, serum proteins constitute a portion of the amino acid pool in the body, and it is believed to be indicative of the nutritional status of the animal. Total protein level in soybean treatment was lower $(p<0.05)$ than that in the treatment with fish oil supplementation when supplemented with different energy sources. The different concentration of total protein in blood serum between SB2 and basal treatment was probably due to the difference in the amount of protein supplemented in the diets [2].

\section{Conclusion}

Different protein sources affected the concentration of blood glucose, bilirubin, cholesterol, total protein and globulin, and different levels of concentrate, soybean oil, and fish oil contributed to the changes in levels of uric acid and protein in cattle blood profiles.

\section{Authors' Contributions}

NTN contributed to the design of the study. NHX and HTL conducted the data collection and analysis. 
NHX and HTL prepared the first draft and NTN did the correction of the manuscript. All authors have read and approved the final manuscript.

\section{Acknowledgments}

This research is funded by Vietnam National Foundation for Science and Technology Development (NAFOSTED) under grant number 106-NN.05-2013.04.

\section{Competing Interests} interests.

The authors declare that they have no competing

\section{References}

1. Verheyen, A.J.M., Maes, D.G.D., Mateusen, B., Deprez, P., Janssen, G.P.J., de Lange, L. and Counotte, G. (2007) Serum biochemical reference values for gestating and lactating cows. Vet. J., 174: 92-98.

2. Klinkon, M. and Ježek J. (2012) Values of blood variables in calves, a bird's-eye view of veterinary medicine. Carlos, C.P.M., editor. ISBN: 978-953-51-0031-7, In Tech. Available from: http://www.intechopen.com/books/a-birds-eye-view-of-veterinary-medicine/values-of-blood-variables-in-calves. Last accessed on 31-07-2017.

3. Mamun, M.A., Hassan, M.M., Shaikat, A.H., Islam, S.K.M.A., Hoque, M.A., Uddin, M. and Hossain, M.B. (2013) Biochemical analysis of blood of native cattle in the hilly areas of Bangladesh. Bangladesh $J$. Vet. Med., 11(1): 51-56.

4. Sharifi, M.R., Shams-Sharg, M., Dastar, B. and Hassini, S. (2011) The effect of dietary protein levels on blood characteristics and carcass yields of Japanese quail (Cortunix cortunix japonica). Ital. J. Anim. Sci., 10-e4: 17-21.

5. Addass, P.A., David, D.I., Edward, A., Zira, K.E. and Midak, A. (2012) Effect of age, sex and management system on some haematological parameters of intensively and semi-intensively kept chicken in Mubi, Adamawa State, Nigeria. Iran. J. Appl. Anim. Sci., 2(3): 277-282.

6. Hassan, M.M.M.A., Hoque, S.K.M., Islam, A., Khan, S.A., Hossain M.B. and Banu, Q. (2012) Efficiency of anthelmintic against parasitic infections and their treatment effect on production and blood indices in Black Bengal goats in Bangladesh. Turk. J. Vet. Anim. Sci., 30(4): 400-408.

7. Ate, I.U., Rekwot, P.I., Nok A.J. and Tekdek, L.B. (2009) Serum electrolyte values of cows during $3^{\text {rd }}$ trimester of pregnancy and early lactation in settled cattle herds in Zaria, Northern Nigeria. Afr. J. Biomed. Res., 12(2): 125-130.

8. Al-Fartosi, G.K.H., Talib, Y.J. and Ali, S.H. (2010) Comparative study of some serum biochemical parameters of cattle and sheep of the marshes in the south of Iraq. AL-Qadisiya J. Vet. Med. Sci., 9(2): 78-84.

9. Dicostanzo, A. and Beka, G. (2012) Cow-calf early fall management tips. In: Beef Cattle. Extension Bulletin. University of Minnesota, United States.

10. Minitab, Inc. (2010) MINITAB 16 Reference Manual. Minitab, Pennsylvania, USA.

11. Kaczmarowski, M., Malinowski, E. and Markiewicz, H. (2006) Some hormonal and biochemical blood indices in cows with retained placenta and puerperal metritis. Bull. Vet. Inst. Pulawy, 50: 89-92.

12. Kumar, R. and Dass, R.S. (2006) Effect of Niacin supplementation on growth, nutrient utilization and blood biochemical profile in male buffalo calves. Asian Aust. J. Anim. Sci., 19(10): 1422-1428.

13. Hammond, A.C. (1983) The use of blood urea nitrogen concentration as an indicator of protein status in cattle. Bovine Pract., 18: 114-118.

14. Alves, M., González, F., Carvalho, N., Mühlbach, P., Lima, V., Conceição, T.R. and Wald, V. (2004) Feeding dairy cows with soybean by-products: effects on metabolic profile. Ciência Rural, 34(1): 239-243.

15. Hassan, M.M., Morsy A.S. and Amal, M. (2013) Egg yolk cholesterol and productive performance of laying hens influenced by dietary crude fiber levels under drinking natural saline water. J. Anim. Poul. Prod., 4(3): 161-176. 